\title{
First Record of Albinism in the Smooth Dogfish Mustelus Schimitti Springer, 1939 (Carcharhiniformes - Triakidae) from Southern Brazil
}

\author{
Simone Ferreira Teixeira ${ }^{1}$ and Maria Lúcia Góes de Araújo ${ }^{2 *}$ \\ 1 Universidade Federal de Pernambuco; Departamento de Oceanografia; Laboratório de Nectologia; Av. \\ Arquitetura, s/n.; CEP 50.670-901; Recife - PE - Brazil; e-mail: sfteixeira@bol.com.br. ${ }^{2}$ Universidade Federal do \\ Amazonas; Departamento de Morfologia; Laboratório de Embriologia; Av. General Rodrigo Octávio Jordão, 3000; \\ CEP 69.000-000; Manaus - AM - Brazil; e-mail: potamotrygon@ bol.com.br
}

\begin{abstract}
This paper reports on a subadult male specimen of the smooth dogfish, Mustelus schimitti, caught in the continental shelf of Rio Grande Sul, during winter of 1993, which exhibited the characteristics of total albinism.
\end{abstract}

Key Words: Albinism, Mustelus schimitti, Carcharhiniformes, Triakidae

\section{INTRODUCTION}

Albinism is a genetics abnormality quite rare in Elasmobranch fishes. This phenomenon has been reported in Rhinoptera bonasus (Schwartz, 1959; Joseph, 1961), Sphyrna lewini (McKenzie, 1970) Stegostoma fasciatum (Nakaya, 1973), in embryos of Mustelus californicus (Talent, 1973), Triakis semifasciata (Follett, 1976), Dasyatis americana (Schwartz and Safrit Jr., 1977) and Carcharhinus amboinensis (McKay and Beinssen, 1987/1988). Nakaya (1973) reported albinos or semi-albinos for four species (Notorynchus maculatus, Raja clavata, Raja naevus and Raja batis).

This paper reports a first record of total albinism in Mustelus schimitti from the continental shelf of Southern Brazil.

\section{MATERIALS AND METHODS}

During the winter of 1993 by the vessel "Nossa Senhora do Carmo" in the continental shelf of Rio Grande Sul ( $\left.33^{\circ} 08^{\prime} \mathrm{S}, 50^{\circ} 47^{\prime} \mathrm{W}\right)$ at $58 \mathrm{~m}$ deep, an albino smooth dogfish Mustelus schimitti was caught. This specimen was preserved in 10\% formalin. Morphometric comparisons were made between the albino and normal specimens. Body measurements were made according to Compagno (1984). All the measurements were taken after the fixation in formalin.

\section{RESULTS AND DISCUSSION}

The albino specimen was a subadult male (Figure 1), measuring $585 \mathrm{~mm}$ of total length (TL) and

\footnotetext{
* Author for correspondence
} 
$775 \mathrm{~g}$. Its age was estimated to be 2.5 years by the equation:

$\mathrm{Lt}=820\left(1-\mathrm{e}^{-0,378(\mathrm{t}+0,917)}\right)$ (Batista, 1988).

The albino's measurements followed the same model of the normal specimen, except the first dorsal fin which had the anterior margin smaller and shorter, with difference of $3.04 \%$ for male and $3.94 \%$ for female. Maximum difference was in the clasper length with $5.10 \%$. The color of normal specimen is gray above light below with numerous white spots (Figure 2). On the other hand, the albino specimen presented the dorsal and ventral surface completely indistinguishable, both white; the irises of the eyes were pink. So we concluded that this specimen was a total albino.

\section{ACKNOWLEDGMENTS}

We thank Ana Catarina Oliveira for her assistance with the albino specimen and the crew of the vessel Nossa Senhora do Carmo for the informations about the capture.

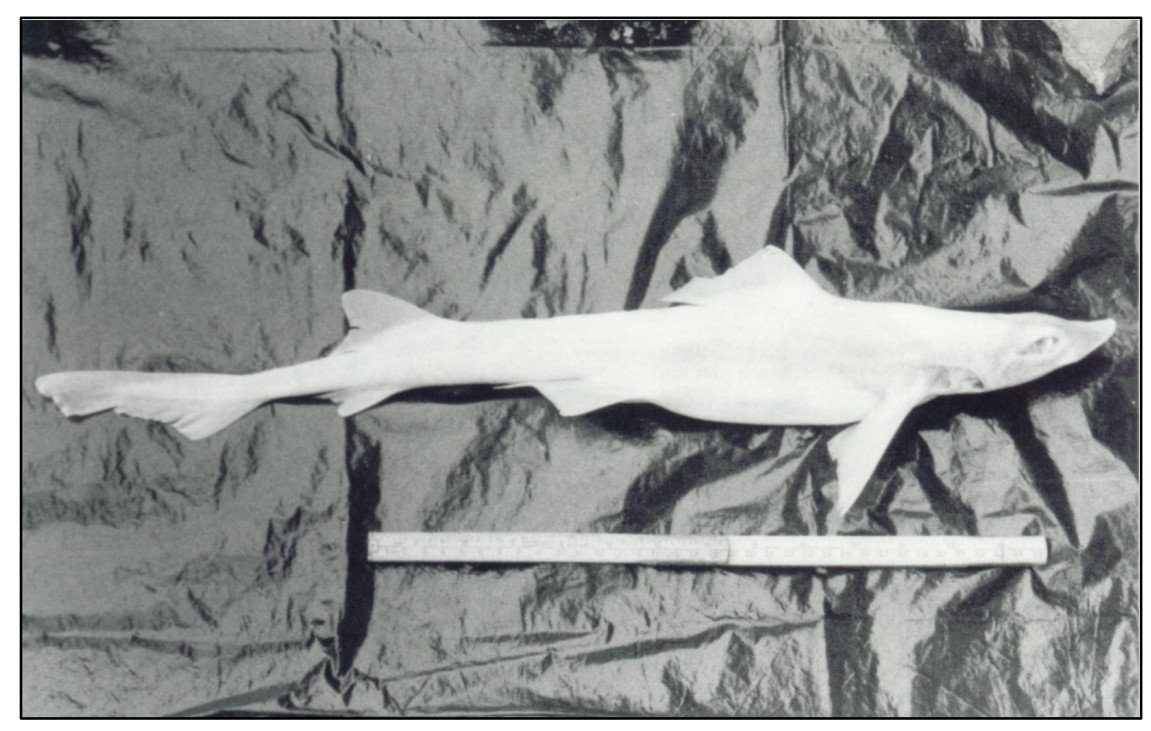

Figure 1 - Albino male smooth dogfish Mustelus schimitti, collected from the Southern Brazil. $585 \mathrm{~mm}$ TL.

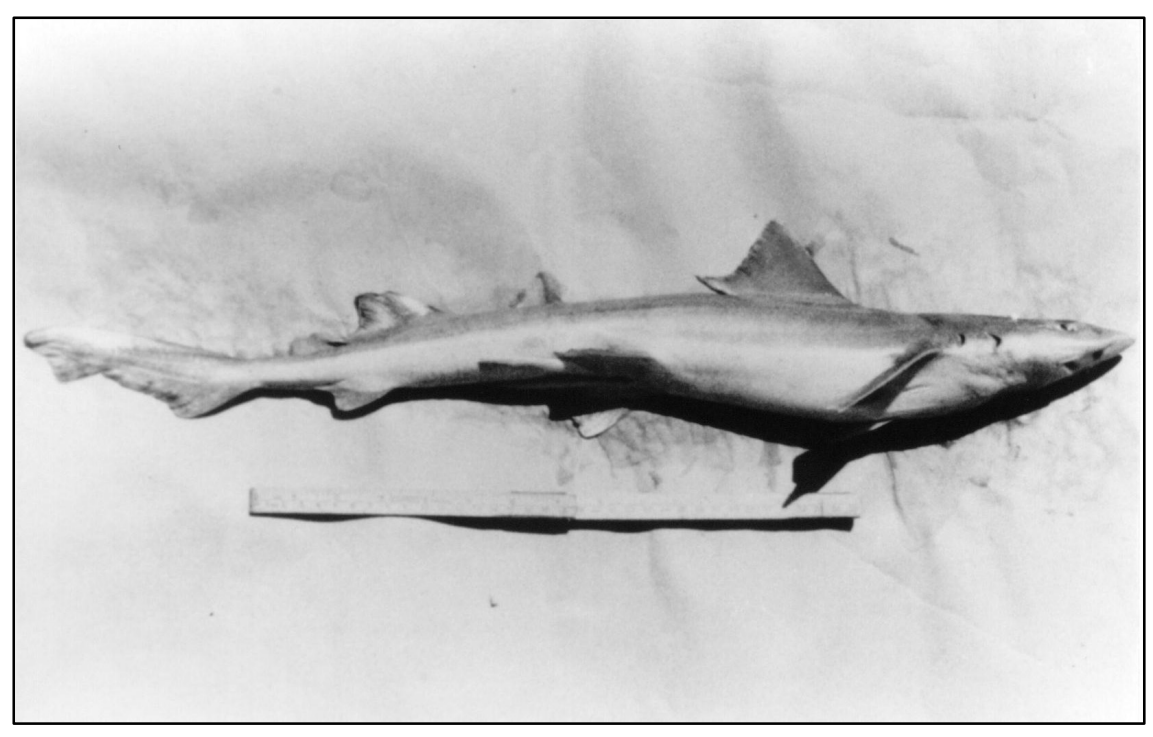

Figure 2 - Normal male smooth dogfish Mustelus schimitti, collected from the Southern Brazil. $653 \mathrm{~mm}$ TL. 


\section{RESUMO}

Este trabalho registra a primeira ocorrência de albinismo total no cação Mustelus schimitti, capturado, no inverno de 1993, na plataforma continental do Rio Grande do Sul.

\section{REFERENCES}

Batista, V. S. (1988), Determinação da idade e análise do crescimento do cação Mustelus schimitti Springer, 1939 (Elasmobranchii - Triakidae) da plataforma continental do Rio Grande do Sul. Rio Grande : Depto. de Oceanografia, Fundação Universidade do Rio Grande. (Dissertação de Mestrado em Oceanografia Biológica). 99 pp.

Compagno, L. J. V. (1984), Sharks of the World. FAO Fisheries Synopsis, 125 : (4), 655.

Follett, W. I. (1976), First record of albinism in the leopard shark (Triakis semifasciata Girard). Calif. Fish Game. 62 : (2), 163-164.

Joseph, E. B. (1961), An albino cownose ray, Rhinoptera bonasus (Mitchill), from Chesapeake Bay. Copeia, 4, 482-483.
McKay, R. J. and Beinssen, K. (1987/1988), Albinism in the pigeye whaler shark Carcharhinus amboinensis (Muller and Henle) from Queensland. Memoirs of the Queensland Museum, 25, 463-464.

McKenzie, M. D. (1970), First record of albinism in the hammerhead shark, Sphyrna lewini (Pisces, Sphyrnidae). J. Elisha Mitchell Sci. Soc., 86 : (1), 35-37.

Nakaya, K. (1973), An albino zebra shark Stegostoma fasciatum from the Indian Ocean, with comments on albinism in Elasmobranchs. Jap. J. Ichthyol., 20 : (2), 120-122.

Schwartz, F. J. (1959), White cownose ray, Rhinoptera bonasus, from Tangier Sound, Maryland. Maryland Tidew. News, 15 : (3), 12.

Schwartz, F. J. and Safrit Jr., G. W. (1977), A white Southern stingray, Dasyatis americana, (Pisces, Dasyatidae), from Pamlico Sound, North Carolina. Chesapeake Sci., 18 : (1), 83-84.

Talent, L. G. (1973), Albinism in embryo gray smoothhound sharks, Mustelus californicus, from Elkhorn Slough, Monterey Bay, California. Copeia, 3, 595-597.

Received: January 02, 2001; Revised: April 05, 2001; Accepted: August 03, 2001. 


\title{
PÁGINA
}

\author{
EM
}

BRANCO 